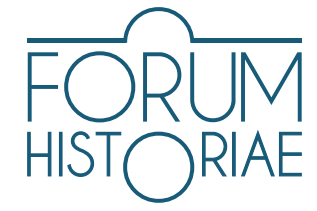

\title{
Not Out of Date, but Out of Time: The Materiality of Zines and Post-digital Memory
}

\author{
Miloš Hroch
}

\begin{abstract}
HROCH, Miloš: Not Out of Date, but Out of Time: The Materiality of Zines and Post-digital Memory. The importance of zines - as documents of history and contemporary media - has recognisably increased in the past decade, and not only media scholars but also historians are paying closer attention to this type of alternative media. We have witnessed both the building of zine archives - digital and physical - and zines being acknowledged as historical resources. Traditionally, zines have been studied from the discursive perspective of subcultures, identities, fan objects and musical genres; therefore, the material component has been overlooked or taken as a matter of course. But with the post-digital situation, the material is more visible and reminds us of the intertwined relationship of the discursive and the material. This paper argues for the possible contribution of media theory to historical research and calls for a deeper understanding of the materiality of zines and the material networks surrounding them as well as the research environment for historians.
\end{abstract}

Keywords: zines, the material, the post-digital, archive, cultural memory, the post-digital memory, new materialism

DOI: https://doi.org/10.31577/forhist.2020.14.1.2

\section{Introduction}

$\mathrm{M}$ ateriality has become increasingly important in the post-digital era. It captures the reconfiguration of our media experience and our exclusive interest in the immaterial digital environment. In other words, the pivotal aspects of our lives have already been digitised, but for different reasons we are returning to analogue media and physical formats - sometimes with a paralysing nostalgia (or rather, as a symptom of the slow cancellation of the future). ${ }^{1}$ Our experience is not limited to this, as novel ways of creatively revising older media in a truly post-digital manner appear. ${ }^{2}$ This approach breaks the cycle, namely it upsets the hegemony of digital immateriality and extends our perception beyond the blue screens and sets of discourses surrounding them to touch and intimacy. Not only media scholars but historians, too, could profit from this perspective.

One specific media form reveals the tactics and aesthetics behind the post-digital in the most demonstrable sense: the particular part of print culture known

1 FISHER, Mark. Ghosts of My Life: Writings on Depression, Hauntology and Lost Futures. London : Zero Books, 2014, p. 14.

2 BLAHA, Agnes - BOULANGER, Sylvie - CARRIÓN, Ulises - CELLA, Bernhard - FINDEISEN, Leo. NO-ISBN on Self-publishing. Vienna : Salon für Kunstbuch, 2017. 
as zines. Zines can take various forms and are produced by different social groups (music subcultures, artists, fandoms). The simplest definition, as offered by Stephen Duncombe, is: "Zines are noncommercial, nonprofessional, small-circulation magazines which their creators produce, publish, and distribute by themselves. ${ }^{33} \mathrm{Zi}-$ nes show the dynamics between the mainstream and the periphery, where printed objects are the megaphones of resistance or are just produced by enthusiasts devoted to the stories and adventures of popular culture. Moreover, they have recently served as historical documents. This turning to the history written in zines is described by Lucy Robinson: "This recent interest in zines from producers (aca) zinesters and researchers can be understood as a turn to the textual past to try and make sense of the digital present. On the one hand, zines and digital social networks produce similar affective networks and identity work. But zines also haunt our digital presents with the pull of the handmade, holdable, shareable objects."

Although the material components of zines - composed of the chaotic aesthetics, worn-out yellow pages, the traces of fading ink and distributed by hand-to-hand contact - are often mentioned ${ }^{5}$ and have been acknowledged by zine researchers, the role of the material has not been fully embraced. So far, it has only played the role of "the elephant in the room" or "humble servants". ${ }^{6}$ Such an approach ignores the interdependent relationship between the discourse and the material. This article follows in the footsteps of Timothy Morton, who called for a rediscovering of the material: "Just as Einstein discovered a rippling, flowing spacetime, where previously objects had just floated in a void, Monet discovered the sensuous spaciousness of the canvas itself, just as later Tarkovsky was to discover the sensuous material of film stock."

With the massive process of digitising zine archives, a certain sense of loss is experienced. The digital immateriality only highlights the long-overlooked aspects of zines and, paradoxically, the material is more visible than ever. This paper calls for a deeper analysis, not only of zine content and zines as objects, but also of the material networks surrounding them. With the building of physical zine archives (or archives of independent culture) there is a whole set of practical and ethical questions concerning how to archive this history without stretching out the material aspect of it. Moreover, the materiality of zines is also important for contemporary production and includes a history which is remediated only in the simplest form of using this (at first sight) "anachronistic" media form. History is still with us and cannot be left behind.

\footnotetext{
3 DUNCOMBE, Stephen. Notes from Underground: Zines and the Politics of Alternative Culture. Portland : Microcosm Publishing, 2008, pp. 10-11.

4 ROBINSON, Lucy. Zines and History: Zine as History. In THE SUBCULTURES NETWORK (eds.) Ripped, Torn and Cut: Pop, Politics and Punk Fanzines from 1976. Manchester : Manchester University Press, 2018, p. 40. 5 HEBDIGE, Dick. Subculture: The Meaning of Style. London : Routledge, 1979, p. 114.

6 LATOUR, Bruno. Reassembling the Social. An Introduction to Actor-Network-Theory. Oxford : Oxford University Press, 2005, p. 73.

7 MORTON, Timothy. Hyperobjects: Philosophy and Ecology after the End of the World. Minneapolis : University of Minnesota Press, 2013, p. 11.
} 
This theoretical study presents a possible contribution of media theory and media materialism for historical research on reflecting the constructing of present-day memory and the irreducible role of the materiality of historical sources. An argument is made for better understanding and analytical exploration of material which is not a passive entity in the process - but at the same time, there is a need to be cautious so as not to set aside the discursive. It is believed that justice can be done to the material by extending current and often used subcultural approaches which would reveal new layers of this alternative media production. But before outlining this discursive-material theoretical model and sketching the possibilities of post-digital memory for (zine) historians, there must be an explanation of the context of the post-digital, and useful approaches in zine research with references to the material need to be contextualized.

\section{Print in the Age of Post-digital}

Throughout the 1980s, we can see an absolute fascination with virtual space, digital technologies and immateriality in popular culture. One of the most well-known and celebrated books of the cyberpunk genre is Neuromancer (1984) by William Gibson, which proposed the radical vision of a future where the world is ruled by corporations; computer hackers are the new heroes operating in cyberspace and a global computer network Matrix mediates consensual illusions. ${ }^{8}$ Cyberculture is a reference point, when speaking about the blurred lines between the material and immaterial. In this sense, Nathalie Casemajor sees the 1980s and 1990s as a vanishing point for the material world and physicality: "Cyberculture partially lost sight of the physicality of digital media in the 1980s and 1990s." Cyberculture created the hegemony of digital as a discourse, and the massive expansion of the internet and digital technologies in the late 1990s and 2000s made it a reality and media became invisible, as Mark Deuze states in his respected book Media Life:"(I)t seems our media are gradually disappearing from view while at the same time influencing our lives more and more in terms of our (real and perceived) control over them and their control over us." ${ }^{\prime 10}$ For at least the past two decades, the fields of media and communication studies have been occupied by digital immateriality. Disciplines have been shaped and focused on the practices and principles of " $n u$ merical representation, modularity, automation, variability and cultural transcoding. ${ }^{111}$ This focus has further stabilised the hegemony of the digital and shifted the focus in academic fields - which is illustrated by the fact that a whole new field of digital journalism has developed. ${ }^{12}$ As a result, the material structure of media has almost completely been forgotten. The way we consume art was radically changed by the streaming culture and digital economies/ecologies. But as a consequence,

8 GIBSON, William. Neuromancer. New York : Ace, 1984.

9 CASEMAJOR, Nathalie. Digital Materialisms: Frameworks for Digital Media Studies. In Westminster Papers in Communication and Culture, 2015, Vol. 10, No. 1, p. 5.

10 DEUZE, Mark. Media Life. Cambridge : Polity, 2012, p. 62.

11 MANOVICH, Lev. The Language of New Media. Cambridge, Massachusetts : MIT Press, 2002, p. 44.

12 ELDRIDGE, Scott - FRANKLIN, Bob (eds.) The Routledge Handbook of Developments in Digital Journalism Studies. Abingdon : Routledge, 2019, pp. 515-526. 
in the past decade we have witnessed an increasing interest in physical media formats, such as music culture's "retromania" symbolised by the rising sales level of vinyl records or cassettes. ${ }^{13}$

This brought to life the renewed popularity of media materialism and media archaeology. Jussi Parikka goes further, arguing for media geology and calling for the further theorisation of the planet's strata as a condition for media. His argument is a "green" one because it acknowledges the environmental impact of our media culture. Parikka emphasises media studies' blindness to the material, although the geological materials of metals and chemicals - which machines and data storage facilities are made of - define our media culture: "Data mining might be a leading hype term for our digital age of the moment, but it is enabled only by the sort of mining that we associate with the ground and its ungrounding. Digital culture starts in-depth and deep times of the planet. Sadly, this story is most often more obscene that something to be celebrated with awe."14

Such a condition is described by the post-digital: the integral parts of our lives have been digitised, paradoxically producing a yearning for environmental consideration of the material which can no longer be ignored. The editors of the reader Across \& Beyond define the term post-digital as an attempt to establish a new way of complex thinking where everything is connected: "The post-digital, then, provides sets of speculative strategies and poetics in an attempt to construct a complex architecture for thinking and creating within contemporary institutional, economic, environmental, and technological constraints and possibilities. ${ }^{.15}$

Post-digital scholars do not exclude material structures of media from the discussion. They care - with the sensitivity of media archaeologists or geologists - not only about digital environments with social media and streaming platforms but also machines, such as smartphones and tablets, as well as the people using those devices and data storage facilities. Print culture with artists, books and zines offer interesting examples to further support this argument; it highlights the importance of media materiality. Books and magazines are read on digital screens, and Alessandro Ludovico, who focuses on post-digital print culture, warns that the digital environment flattens the experience of a written text, as the sensual dimension disappears with screens. In terms of sight, paper invites more factors into perception, such as daylight and reflections of light, and highlights the materiality: "Tactility gives direct information without other senses involved. For example, readers familiar with a specific book would be able to recognise it from the texture of its cover and its size."16

13 REYNOLDS, Simon. Retromania: Pop Culture's Addiction to its Own Past. London : Faber \& Faber, 2012, pp. 350-352

14 PARIKKA, Jussi. The Anthrobscene. Minnesota : University of Minnesota Press, 2014, p. 35.

15 BISHOP, Ryan et al. (eds.) Across \& Beyond: A Transmediale Reader on Post-digital Practices, Concepts, and Institutions. Berlin : Sternberg Press, 2016, p. 13.

16 LUDOVICO, Alessandro. The Touching Charm of Print. In BISHOP, Ryan et al. (eds.) Across \& Beyond: $A$ Transmediale Reader on Post-digital Practices, Concepts, and Institutions. Berlin : Sternberg Press, 2016, p. 106. 
Printed objects can serve as a contemporary shield against the digital delirium: stable and static zones of empathy and intimacy between reader and writer/artist. They coexist with the digital and are hardly separable from the online world. The role of print has to be redefined in the contemporary media landscape - with the growth of e-books, the materiality regains importance. "Paradoxically, it is this very immutability of paper which is now increasingly proving to be an advantage rather than a weakness, particularly in the context of an ever-changing (thus ephemeral) digital publishing world."17 We can see how the digital incorporates the interface of a printed book, while on the other hand, we can follow traces of the digital in print - the logics of hypertexts, web links leading e. g. to streaming services, printed photos taken from Instagram or even augmented reality included in books and zines. The spheres of digital and print have to converge in a more effective way. "And so this new generation of publishers, able to make use of various new and old media without the burden of ideological affiliation to any particular one of them, will surely be in a position to develop new and truly hybrid publications, by creatively combining the best standards and interfaces of both digital and print."18

\section{Zines}

When speaking about the possibilities of printed matter, zines are the most experimental platform because they are easy to create and cheap to print. In media theory, zines are positioned in the alternative media paradigm. One of the most common definitions, as expressed by Stephen Duncombe, states that: "Zines are noncommercial, nonprofessional, small-circulation magazines which their creators produce, publish, and distribute by themselves."19 Such niche media carry counter-hegemonic discourses and representations, ${ }^{20}$ are participatory with non-hierarchical structures, are small-scale and not produced for financial reward (but to cultivate community, support diversity or cultural/social change) and made by amateurs (fans, subcultures, activists, artists) who create alternative distribution and production sites. Chris Atton writes that alternative media are - among others - defined by radical visual content or "employment of reprographic innovations". ${ }^{21}$ This suggests that zine communities are very material and inter-material, as various materials and printing machines are involved in the production, and zine communities are therefore an assemblage of different bodies, spaces, objects, machines and capital.

As indicated above, the material displays itself within the zine medium in various forms by the practice of graphic design, which has deeper roots in art history: it resembles the technique of recontextualisation of images or texts influenced by Dadaist and Situationists' strategies or William Burrough's "cut-up" method:

17 LUDOVICO, Alessandro. Post-Digital Print. The Mutation of Publishing since 1894. Eindhoven : Onomatopee, 2012, p. 155.

18 LUDOVICO 2012, p. 117.

19 DUNCOMBE 2008, pp. 10-11.

20 CARPENTIER, Nico. The Discursive-Material Knot: Cyprus in Conflict and Community Media

Participation. New York : Peter Lang Publishing, 2017, p. 132.

21 ATTON, Chris. Alternative Media. London : Sage, 2002, p. 27. 
"The folding of one text onto another, which constitutes multiple and even adventitious roots (like a cutting), implies an additional dimension to that of the texts under consideration. In this extra dimension of folding, unity continues its spiritual labour."22 Graphic design of early punk fanzines - which defined the zine visuality - was described as "cut \& paste" in reference to the tools used: scissors and glue. Traces of hardly readable words, ink stains, hair and fingerprints were left on the pages. Such a chaotic layout points to another material dimension of zines: that of intermateriality, referring to the presence of various materials and layers within the same object. The editors of the reader Ripped, Torn and Cut, in a rare reference to the material, describe this element as the embodiment of aesthetics in the physical object: "Fanzines, then, became an integral part of punk's challenge; the literary and visual embodiment of 'do it yourself." ${ }^{3}$

Such traces are not only helpful to media scholars, but also to historians, as Lucy Robinson shows: "Zines help us trace the history of how we write our own histories and how we network around the histories of those who share stories with us [...]. In particular, zines intersect with and bring something new to tensions around identity and DIY histories." ${ }^{\prime 24}$ Laura Oldfield Ford's zine Savage Messiah is the perfect example of a zine, which can be read as a document of history (Mark Ford observes the transformation of the city of London as a space where the zine is produced). Additionally, it reveals the history as a medium - in the way that it is made and by the assemblage of older printing technologies. "Savage Messiah deploys anachronism as a weapon. At first sight, at first touch - and tactility is crucial to the experience: the zine doesn't feel the same when it's JPEGed on screen - Savage Messiah seems like something familiar. The form itself, the mix of photographs, typeface-text and drawings, the use of scissors and glue rather than digital cut and paste; all of this make Savage Messiah seem out of time, which is not to say out of date."25

Such an anachronistic attitude in zine-making is significant in the post-digital. For a myriad of reasons, people are returning to older printed media, fading printing techniques and craft. While our culture is driven by the modernist yearning for the new as well as a capitalist logic which urges consumers to constantly buy updated technologies, the post-digital situation makes us reconsider the categories of new and old media and radically remix them - old media do not die, as was predicted for print culture decades ago, and they carry their history with them. This is mostly demonstrated on zines which are resurrected with post-digital sensitivity. In the new condition, zines are "not out of date, but out of time".

22 DELEUZE, Gilles - GUATTARI, Félix. A Thousand Plateaus: Capitalism and Schizophrenia. Minneapolis : University of Minnesota Press, 1987, p. 6.

23 WORLEY, Matthew et al. Introduction: Adventures in Reality: Why (Punk) Fanzine Matter. In THE SUBCULTURES NETWORK (eds.) Ripped, Torn and Cut: Pop, Politics and Punk Fanzines from 1976. Manchester : Manchester University Press, 2018, p. 4.

24 ROBINSON 2018, p. 42.

25 FISHER, Mark. Always Yearning for the Time That Just Eluded Us. In FORD, Laura Oldfield (ed.) Savage Messiah. London : Verso Books, 2011, p. x. 
We have also witnessed the strong movement of printed publications which are mainly visual-symbolic objects. As a consequence: the use of machines, such as a Xerox copier or Risograph, or even the weight of the paper, defines the identity of a zine as equally as the content - and zines are not only read but also tactilely sensed and experienced. In the pre-digital era zines were defined as an antidote to magazines, ${ }^{26}$ but in the post-digital they have another dimension to position themselves against - the digital environment. As elaborated by Florian Cramer: "Such practices can only be meaningfully called post-digital when they do not merely revive older media technologies, but functionally repurpose them in relation to digital media technologies." 27

\section{Reaching the Material}

There is strong potential for reaching and incorporating the material in two of the analytical models most commonly used by subcultures/fan/zine, namely Bourdieu's field theory ${ }^{28}$ and the classic of cultural studies, Stuart Hall's concept of discourse. ${ }^{29}$ It is necessary to keep in mind that Hall's and Bourdieu's takes on materiality are still very much concerned with meaning. However, the crux of their arguments makes a good segue to my argument. Accordingly, I will briefly outline their ideas to expose them as a possible entry point for deeper analysis of the material.

Hall's communication model of encoding/decoding (1973) ${ }^{30}$ helped to establish audiences as actively decoding the meanings by mainstream media - and this premise defined further research in cultural studies. What may be considered surprising and exceptional in Hall's discursive theory is the thought given to the extra-discursive and the material aspect of social reality: "Nothing which is meaningful exists outside discourse. ${ }^{\prime 31}$ He saw politics through the meanings and representations of (sub)cultures, which were manifested by dissonant music, colourful hairstyles and, last but not least, the pages of zines: "Culture has ceased (if ever it was - which I doubt) to be a decorative addendum to the 'hard world' of production and things, the icing on the cake of the material world. The word is now as 'material' as the world."32

26 DUNCOMBE 2008, p. 18.

27 CRAMER, Florian. What Is Post-Digital. In A Peer-Reviewed Journal about Post-digital Research, 2014, Vol. 3, No. 1, p. 14 .

28 DUFFET, Mark. Understanding Fandom: An Introduction to the Study of Media Fan Culture. New York : Bloomsbury, 2013, pp. 219-222; CHIN, Bertha. It's About Who You Know: Social Capital, Hierarchies and Fandom. In BOOTH, Paul (ed.) A Companion to Media Fandom and Fan Studies. Oxford : John Wiley \& Sons, 2018, pp. 243-255.

29 STREET, John. Politics and Popular Culture. Philadelphia : Temple University Press, 1992, p. 154.

30 HALL, Stuart. The Determination of News Photographs Chapter. In COHEN, Stanley - YOUNG, Jock (eds.) The Manufacture of News: Social Problems, Deviance and the Mass Media. London : Constable, 1973, pp. 226-247.

31 HALL, Stuart. Representation: Cultural Representation and Signifying Practices. London : Sage, 1997, p. 44. 32 HALL, Stuart. The Meaning of News. In MORLEY, David - CHEN, Kuan-Hsing (eds.) Stuart Hall: Critical Dialogues in Cultural Studies. Abingdon : Routledge, 1996, p. 232. 
Similarly, Pierre Bourdieu developed the model for understanding the social reality, which is organised and structured by sets of fields ${ }^{33}$ with a noticeable sense for the material: "Every material inheritance is, strictly speaking, also a cultural inheritance." ${ }^{\prime 34}$ Without necessarily going deeper into Bourdieu's theory, the focus on material structures is evident. In his respectable analysis of the French literary field in the 19th century, he pays close attention to details regarding the relationships of publishers, authors and readers. He studies their works and creates mental maps of the literary field which includes, for instance, discussions in literary salons - the key aspect of Bourdieu's analysis is contextualisation: how subjects, objects, actors and spaces relate to each other. ${ }^{35}$ Such focus on spaces or objects (of materialised art) led Randall Johnson to state that: "In Bourdieu's theory, symbolic aspects of social life are inseparably intertwined with the material conditions of existence, without one being reducible to the other."36 Erik Neveu emphasises Bourdieu's references to the material in the same sense: "Bourdieu energetically fought semiological approaches, and nevertheless in practice constantly devoted close attention to the forms and materiality of media and cultural products." ${ }^{27}$

For actors to succeed in (or across) each field means to differentiate one from another, which is connected to taste - Bourdieu did not perceive taste as a question of one's choice, but rather as an indicator of class background and whole social system. ${ }^{38}$ Sarah Thornton (1995) elaborated on Bourdieu's concept of taste, fields, habitus and capital to create a sociological model for rave/dance/club music. She analysed hierarchies within "club cultures" and simultaneously shifted attention to underground and fashion media, while assuring the material components of the field: "But these cryptic cultural values have material foundations; they relate to the economic, social, cultural and media conditions in which they were generated."39 To do so, Sarah Thornton developed the concept of subcultural capital, which can take different forms and does not represent only knowledge or skills, but also collections of material objects: "Subcultural capital can be objectified or embodied. Just as books and paintings display cultural capital in the family home, so subcultural capital is objectified in the form of fashionable haircuts and well-assembled record collections (full of well-chosen, limited edition 'white label' twelve-inches and the like)."

33 For instance, the cultural field, educational field, academic field or even linguistic field, in which case each field is organized and hierarchized by the distribution of capital, and capital creates the set of skills and dispositions, habitus.

34 BOURDIEU, Pierre. Distinction: A Social Critique of the Judgement of Taste. Cambridge, Massachusetts : Harvard University Press, 1984, p. 99.

35 BOURDIEU, Pierre. The Field of Cultural Production. Cambridge : Polity Press, 1993, pp. 145-215.

36 JOHNSON, Randall. Editor's Introduction: Pierre Bourdieu on Art, Literature and Culture. In BOURDIEU, Pierre. The Field of Cultural Production. Cambridge : Polity Press, 1993, p. 4.

37 NEVEU, Erik. Bourdieu, the Frankfurt School, and Cultural studies: On Some Misunderstandings. In BENSON, Rodney - NEVEU, Erik (ed.) Bourdieu and the Journalistic Field. Cambridge : Polity, 2005, p. 202.

38 DUFFET, Mark. Understanding Fandom: An Introduction to the Study of Media Fan Culture. New York : Bloomsbury, 2013, p. 221.

39 THORnTON, Sarah. Club Cultures: Music, Media and Subcultural Capital. Cambridge : Polity, 1995, p. 61.

40 THORNTON 1995, p. 27. 
As has been shown, the material is present in zine research, but not yet fully inscribed with active and generative power - this creates an imbalance, which can be eliminated only by bringing new analytical concepts and vocabulary to the table. To give one good example, and the possibilities will be more outlined than fully developed, this could provide insight from the new materialism. The material highly resonates in current debates about environmental issues and is being rethought by the philosophers of new materialism. New materialists radically acknowledge the existence of a material world that is independent of our minds, as described by Manuel DeLanda on a larger scale: "It is absurd to think that complex self-organising structures need a 'brain' to generate them. The coupled system atmosphere-hydrosphere is continuously generating structures (thunderstorms, hurricanes, coherent wind currents) not only without a brain but without any organs whatsoever."11 This sensitivity is visible in art, where the material is fully embraced. ${ }^{42}$ Morton's analysis of the drone music of the avant-garde composer La Monte Young further serves as a perfect example of how to focus on the material even where it is not as evident by touch: "[...] the material that generates a sound, such as the wood and strings and open body of a sitar. What resonates in just intonation, for example - music based on whole number harmonic intervals, such as Indian music - is a profound range of materiality. It is like the 'diabolical', ghoulish materiality of atonal music, but colored brilliant violet, magenta, and viridian." ${ }^{\prime 3}$

In contrast with Hall and Bourdieu, the new materialism tends to be post-humanist as it attempts to transcend the focus on meaning and to pay more attention to the matter. Privileging the material serves as an argument against the dualisms (nature-culture, human-inhuman, discursive-material) that have been present across scholarly fields for decades - with the long-term goal of bringing balance and to study them in their entanglement. ${ }^{44}$

The task is how to introduce the discursive and the material and overcome stabilised dichotomies, to reach the point where two different paradigmatic positions can meet and learn from each other - one with the meaning as a starting point, the other with the material. This is not the first attempt to introduce the discursive and the material. ${ }^{45}$ Most recently, Nico Carpentier (2017) created the useful theoretical framework of a discursive-material knot - where the metaphor of the knot serves as a perfect binder and is supported by the Deluzian metaphor of assemblage (highlighting symbiosis, cooperation, sympathy), which helps to translate this entanglement into social practice. The discursive and material share the same space, and both are articulated in the non-hierarchical relationship,

41 DeLANDA, Manuel. Interview with Manuel DeLanda. In DOLPHIJN, Rick - VAN DER TUIN, Iris (eds.) New Materialism: Interviews \& Cartographies. Michigan : Open Humanity Press, 2012, p. 43.

42 PARIKKA 2014, p. 7.

43 MORTON 2013, p. 169.

44 DOLPHIJN, Rick - VAN DER TUIN, Iris (eds.) New Materialism: Interviews \& Cartographies. Michigan : Open Humanity Press, 2012.

45 HARAWAY, Donna J. Simians, Cyborgs and Women. The Reinvention of Nature. New York : Routledge, 1991, p. 192; BARAD, Karen. Post-humanist Performativity: Toward an Understanding of How Matter Comes to Matter. In Signs, 2003, Vol. 28, No. 3, p. 821. 
where one influences the other: "...the material is always invested with meaning." ${ }^{\prime 4}$ The metaphor of the knot is important here: you cannot untie knotted spheres of the discourse and the material, because each sphere influences the other the material carries meaning and discourse has a material form, both influence each other. "The discursive-material knot is a non-hierarchical ontology that theorises the knotted interactions of the discursive and the material as restless and contingent, sometimes incessantly changing shapes and sometimes deeply sedimented. But this relation of interdependence will never result in one component becoming more important than the other." ${ }^{\prime 7}$ With Nico Carpentier, we applied this framework on zine culture in the case study of the Prague zine scene. ${ }^{48}$

\section{Conclusion}

Introducing the new materialism into the research will help to see zine production and distribution, and the zines as objects themselves with different eyes having a specific focus on thrashed pages and piled up layers of content, imperfections and the employment of anachronistic production technologies. The material is always invested with meaning, while at the same time meaning has its own material structure. This also applies to zines, which are simultaneously representational and material - and both media theory, as well as history, have to take this into account, since both spheres influence and shape each other. A better theorisation of zine materiality can help us to understand their meaning in a novel way.

Moreover, this approach may reveal the impact of changing self-publishing practices on zine content; the focus on the use of different technologies can also show how machines have affected zine production and aesthetics and the thinking of zine makers. Furthermore, the emphasis on ageing materials may generate new findings about media temporality and how history is remediated. This specific discursive-material focus will also help to better understand the materiality of archives where zines are stored and more generally the environment where historians work - and simultaneously take into account environmental contexts and impacts.

Zines remediate former media forms - for instance, by "analogisation" when the neglectful Xerox print patina is recreated with the use of graphic design software. As was shown in the case of Savage Messiah, zines also offer a new experience of the space and create cultural memory sites on their own - and therefore the zine presents history as a matter of both private and public. Erll \& Rigney write about cultural memory relying on this re-using of media: "In this process, memorial media borrow from, incorporate, absorb, critique and refashion earlier memorial media. Virtually every site of memory can boast its genealogy of remediation, which is usually tied to the history of media evolution." ${ }^{\prime 9}$

46 CARPENTIER 2017, p. 73.

47 CARPENTIER 2017, p. 4.

48 HROCH, Miloš - CARPENTIER, Nico. Beyond the Meaning of Zines: A Case Study of the Role of Materiality in Four Prague-based Zine Assemblages. Manuscript in review.

49 ERLL, Astrid - RIGNEY, Ann (eds.) Mediation, Remediation, and the Dynamics of Cultural Memory. New 
Digital immateriality affects our sense of time; as a result, past, present and future collide. ${ }^{50}$ Material media may serve as an arrow pointing the direction on an imaginary timeline. Printed media in this sense become not out of or up to date, but out of time, as history and the present have to coexist with the promise of cracking up the possible futures - which will be touchable and material.

The post-digital strategies influence our cultural memory; therefore, they promise new possibilities for (transmedia) cultural memory sites in the way in which old media can be revised, situating them in a distinctive era without leaving out the material aspect of it. As Andrew Hoskins affirms the matter-of-course, technologies and the way people use them also impacts the memory: "Contemporary memory is thoroughly interpenetrated by a technological unconscious in that there occurs a 'co-evolution' of memory and technology. Memory is readily and dynamically configured through our digital practices and the connectivity of digital networks." ${ }^{\prime 51}$ Lucy Robinson emphasises that we can learn from the experiences (of resistance or fascination): "Different archival approaches capture different elements of zines' movement from past to present and into imagined futures."52

With the foundation of new digital collections, such as ZineWiki, Open Culture or the local Czech and Slovak Archive of Subcultures, the development of post-digital memory practices can contribute: it changes our view of archives, how such spaces are transformed and how scholars operate within them. The massive digitising wave will not change the fact that archived documents are still material objects with their specific quality - this tactility and hapticity cannot be lost.

York : Walter de Gruyter, 2009, p. 5.

50 GANSING, Kristoffer. 1995: The Year the Future Began, or Multimedia as the Vanishing Point of the Net. In BISHOP, Ryan et al. (eds.) Across \& Beyond: A Transmediale Reader on Post-digital Practices, Concepts, and Institutions. Berlin : Sternberg Press, 2016, pp. 29-44.

51 HOSKINS, Andrew. Digital Network Memory. In ERLL, Astrid - RIGNEY, Ann (eds.) Mediation, Remediation, and the Dynamics of Cultural Memory. New York: Walter de Gruyter, 2009, p. 96.

52 ROBINSON 2018, p. 41.

Cituj:

HROCH, Miloš. Not Out of Date, but Out of Time: The Materiality of Zines and Post-digital Memory. In Forum Historiae, 2020, Vol. 14, No. 1, s. 17-27. ISSN 1337-6861. DOI: https://doi.org/10.31577/ forhist.2020.14.1.2

Mgr. Miloš Hroch

Institut komunikačních studií a žurnalistiky

Fakulta sociálních věd Univerzity Karlovy

Smetanovo nábř. 6

11001 Praha 1, Česká republika

E-mail: milos.hroch@fsv.cuni.cz

http://orcid.org/0000-0001-6590-595X 